\title{
Profit and Loss Allocation among Islamic Bank and Client Partner in Equity Financing: Practice, Precepts and Alternatives
}

\author{
Muhammad Abdurrahman Sadique \\ Assistant Professor \\ Dept. of Islamic Law - Ahmad Ibrahim Kulliyyah of Laws \\ International Islamic University Malaysia, Malaysia \\ abdmsm@yahoo.com / sadique@iium.edu.my
}

Abstract. The profit sharing ratio in equity financed projects is decided by Islamic banks mainly through applying the relevant rate of return on capital. After first determining the return sought by the bank, the remainder of the expected profit is usually taken as the share of the joint partner, and the proportion adopted as the profit sharing ratio.

Ideally, the profit sharing ratio should be decided through a mutual process considering the contributions of both partners, with due recognition of the level of liability each had borne. The period, as a factor common to the joint venture, could be redundant. Hence, the profit sharing ratio should be reflective of the capital and labour outlay of both the bank and the client, to the extent possible.

In view of the socio-economic function expected of Islamic banks, the method for profit ratio calculation adopted should adequately consider the actual contributions of both partners. Two bases possible are giving capital and labour of both partners equal weightage, and giving capital a weightage different from labour. 


\section{Introduction}

The profit and loss sharing scheme prescribed by the Islamic Shariah in joint enterprises intends to achieve a just distribution of gain and liability among the joint partners. Taking the ideals and guidelines propounded by the Shariah and the prevailing conditions into consideration, this paper examines the acceptability of the process generally adopted by Islamic financial institutions for determining the profit sharing ratio in projects financed on joint equity basis. The discussion is mainly relevant to adopting the equity basis in financing ventures where the capital is jointly funded by both the financial institution and the client ${ }^{(1)}$. Thus, the process of determining the profit sharing ratio analysed in the paper is not directly relevant to the ratio adopted for division of profits between the depositors of the institution and the share holders. Although the main thrust of the discussion is centred on joint equity based financing, i.e. musharakah, a major portion of it is also relevant to financing on the basis of mudarabah, where the venture managed by the client is solely funded by the bank. The paper attempts to suggest alternative bases for profit ratio determination in equity based financing of ventures that could facilitate realisation of the socioeconomic goals of Islamic Shariah.

\section{Current Method of Determining the Profit Distribution Ratio}

Instead of stipulating a return based on the capital extended as practised by conventional banks, in financing ventures on musharakah and mudarabah, Islamic banks are required to agree on a profit sharing ratio so as to comply with Shariah guidelines. Equity financing of single transactions that are short term in nature involve single exports and imports, financing of produced goods etc, while financing of projects involving production and manufacture could extend over longer terms. In determining the profit sharing ratio in such ventures the bank primarily takes into account the envisaged rate of return on capital, usually also considering factors such as the size of the investment and the period of exposure, i.e. the duration taken for realisation of profits or alternatively, liquidation. Usually, ancillary factors such as the nature of risks involved, additional business income that could be generated through other means from the same client and his credit record, too, are kept in view. It is pertinent to examine the method through which Islamic banks determine the profit sharing ratio in such equity ventures.

Determination of the profit sharing ratio in joint enterprises is primarily done by Islamic banks through ascertaining the amount of return it intends to

(1) "Client" here means the party that approaches the bank for obtaining funds, i.e. the party referred to as borrowers in conventional banking. It is does not mean the depositors. 
realise on its capital exposure ${ }^{(2)}$. This is done through multiplying the amount of capital sought to be invested by the bank by the appropriate rate of return and by the expected period, arriving at the net return the bank wishes to realise through the venture. The rate could be marginally altered in view of the other factors referred to above, especially in the case of larger exposures, based on negotiation. In the case of smaller exposures, more often than not, the role played by negotiation happens to be minimal. Thereafter, the envisaged return thus calculated is divided by the expected total profit projected for the venture for obtaining the ratio of the bank's share in the profits. This means that the return sought by the bank is compared with the total profit the venture is expected to yield, and is then reflected as a proportion of it. After the bank has determined the amount of return it wishes to achieve, the remainder of the expected profit, irrespective of its size, is taken as the profit share of the client / joint partner, and the proportion of one to the other is held as the ratio of profit sharing. Since this method fundamentally aims at the bank achieving a predetermined return on the capital invested in the equity venture, it is necessary to scrutinize the level of its appropriateness Islamically in joint ventures based on mutual sharing and joint participation.

As evident, the period of exposure, usually counted in months, is taken as the most important variable in the determination of the bank's profit share. Consequently, a venture expected to take a longer term for completion would invariably involve a higher share of profit being allocated to the bank. The other component, i.e. the rate of return, could alter marginally based on the other factors mentioned above. Owing to this state of affairs, it is seen that any negotiation with the potential partner on the bank's capital infusion almost exclusively centres on the monthly rate to be applied, along similar lines as when a conventional banking facility is applied for. The rate of return applied to different types of equity investments is almost always parallel to the corresponding lending rates for similar facilities in conventional banks, and no substantial change is observed to occur in view of the profitability of a venture. This scenario is largely attributed to the competition offered by conventional

(2) Many institutions financing by way of murabahah determine their profit or mark-up on the basis of the current interest rate, mostly using LIBOR (London inter-bank offering rate) as the criterion (Muhammad Taqi Usmani, An Introduction to Islamic Finance, 118; Mohammed Obaidullah, Islamic Financial Services, 74, 91). Calculating the bank's profit in this manner is not limited to murabahah, but is common to many types of financing undertaken by banks, including equity based facilities, as close observation of the Islamic banking practice would indicate. See Muhammad Abdurrahman Sadique (2006), "A study of equity financing modes for Islamic financial institutions in a Shari'ah perspective," unpublished doctoral thesis, International Islamic University Malaysia, p. 188; Shahid Hasan Siddiqui, "Instruments of Islamic banking in operation", <http://jang.com.pk/thenews/apr2008weekly/busrev-28-04-2008/p6.htm> 
banks, whose presence has a curtailing effect on profit rates that could be demanded by Islamic banks. It is feared that potential equity partners would prefer loan capital at relatively low rates of fixed interest to risk capital with a higher demand on potential profits. Thus the interest rate on loan capital extended by conventional banks is taken as the primary basis for determining the rate of return on the risk capital invested in equity ventures, and more often than not, the liability borne by the bank through investing based on a profit and loss sharing platform is not given sufficient room to play an effective role in this process.

At the conclusion of the project as expected, the bank succeeds in achieving the return on its capital as dictated by the rate applied. Any additional amount of profit over and above the sum projected initially could only result if the venture succeeds in realizing a higher profit than was anticipated. In this event, by virtue of the share of the bank being fixed as a ratio of the total profit and not as a lump sum or a percentage of the initial capital outlay, the bank would be entitled to a higher return, irrespective of the amount. However, it should be noted that the possibility of earning such a higher return is minimal due to banks entertaining only ventures that lead to a definite return, and incorporation of additional clauses that make the client entitled to any profit earned over and above a stipulated ceiling ${ }^{(3)}$.

\section{Evaluation of the current method}

In the current method, generally the rate of return on capital is taken as the basis for the calculation of the profit ratio, where the period of the exposure acts as the major variable. The process of determining the profit sharing ratio in joint ventures financed by Islamic banks, therefore, starts from the amount of capital invested by the bank in the venture. Consequently, the process is largely similar to fixing a margin of profit in trading products offered by Islamic banks such as ijarah and murabahah. Reflection of the return sought by the bank as a percentage of the capital ceases only at the final stage of concluding the musharakah/mudarabah contract, at which point the amount is converted into a percentage of the total profit expected and recorded as such in the agreement, principally for the purpose of Shariah compliance.

It is observed that due to adopting a mechanism designed to achieve a defined return, the profit share accruing through a venture yielding high profits is not significantly different from that achieved through one that is lower in profits. Therefore, an adverse effect of employing this method in equity

(3) The Shariah perspective of such clauses affecting the functioning of the profit sharing ratio has been addressed by the author in a separate research. 
ventures is that the profitability of the venture is prevented from playing an adequate role in determining the profit sharing ratio. Thus, the profitability of the venture would not necessarily bring about a higher return to the bank, usually the major provider of capital, and through it, to the bank's investors, as the profit share is determined on the basis of a specific amount of profit the bank desires to generate through the project. This in turn restricts to a large extent a primary role Islamic banks are envisaged to play, viz. facilitating an equitable distribution of wealth among entrepreneurs and principal owners of funds. Consequently, the investors of the bank are generally observed to receive a flat return that does not adequately reward them for the risk capital they had provided, even when the projects funded through their monies realise huge profits. Fundamentally, this could reflect the anomaly arising out of juxtaposing a capital-centred rate of return method within a profit-centred shirkah framework.

In the current method, the primary emphasis is placed on the time factor, which is conceived as the fundamental basis for multiplication of the return. However, it could be observed that ideally, the expected period for the realization of profits/ liquidation should not play a role in determining the profit share of any single partner. This is because time, being a factor that affects the venture as a whole and consequently, the interests of both partners, should be regarded as a common element, and its impact on the profit sharing ratio overall should be zero. Thus, there appears no justification for the Islamic bank unilaterally adopting a profit share calculation mechanism that fundamentally depends on the element of period for fixing its own share of profit exclusively. A true implementation of equity financing could demand that the element of time be excluded from playing a role in fixing the profit share of one partner to the exclusion of the other.

The Shariah principle with regard to distribution of profit both in musharakah and mudarabah is that the profit shares of partners should be fixed as a ratio of the total profit realizable through the venture ${ }^{(4)}$. It is due to this reason that fixing a lump sum or a ratio related to the capital as the profit share of any partner has been ruled inadmissible. Fixing a ratio of the capital as the profit share too is essentially tantamount to fixing a lump sum, as the capital

(4) See for the ruling in musharakah: al-Kasani, Bada' $i$ ' al-Sana'i', Bayrut, Dar al-Ma'refah, 2000, vol. 6, p. 94, Ibn Qudamah, al-Mughni, Bayrut, Darul Fikr, 1992, vol. 5, p. 140, alNawawi, Rawdah al-Talibin, Bayrut, Dar al-Kutub al-'Ilmiyyah, vol. 3, p. 516, al-Khurashi, Hashiyah al-Khurashi, Bayrut, Dar al-Kutub al-'Ilmiyyah, 1997, vol. 6, p. 349; for the ruling in mudarabah, see: Ibn Qudamah, al-Mughni, vol. 5, p. 142, al-Nawawi, Rawdah alTalibin, vol. 4, p. 203, al-Kasani, Bada' 'i' al-Sana 'i', vol. 6, p. 135, al-Khurashi, Hashiyah al-Khurashi, vol. 7, p. 151. 
being definite and fixed, a share proportionate to it also is definite. In the process discussed above, the profit is primarily determined as a percentage of the capital for all intents and purposes, although converted into a share of the total profit at the time of concluding the contract. This latter measure is considered sufficient to ensure Shariah validity of the contract apparently on the basis that, as long as a ratio is fixed for profit distribution between the partners without assigning a lump sum profit to any, the exact process through which the partners choose to determine the ratio is not of material relevance. However, it would be pertinent to examine the extent of the effect of such conversion on the reality of the transactions.

Possibly due to ingrained elements of extreme risk aversion inherited from the conventional culture of lending against fixed interest, Islamic banks are still not noted to be favourably inclined towards investment in open trade, where profits are not secured in one way or the other. A fair number of enterprises that Islamic banks agree to finance on an equity sharing basis comprise ventures involving a near certain amount of profit ${ }^{(5)}$. Thus, although exceptions do exist in the form of equity-based project financing, a good proportion of equity based facilities extended currently involve ventures where the return is fairly secure, such as financing of exports against letters of credit, financing of manufacture against a confirmed order, financing of imports involving goods that have a ready-made market etc. In these instances, the margin of fluctuation in profitability is almost negligible, as the profits realizable could be projected to a near-certainty. Therefore, the primary purpose of fixing the profit share of each partner as a proportion of the total profit, viz. to allow variation of the profit share according to fluctuation in the profit levels actually realized, remains hypothetic to a great extent. In this scenario, it could be said that conversion of the profit rate calculated initially as a lump sum return on the capital invested by the bank into a percentage of the net profit only serves the purpose of achieving Shariah admissibility. The effect of fixing a profit ratio related to net profit thus could become apparent only in the unlikely event of an unforeseeable loss befalling the venture. As far as the reality is concerned, the investment is designed to achieve a fixed return as calculated based on the capital invested. Consequently, although a direct violation of the Shariah requirement is avoided through converting the expected return on capital to a proportion of the expected profit, the process could not be held to be indicative of intent at a genuine sharing of the profits.

The appropriateness of employing this technique in fixing the profit sharing ratio relating to musharakah / mudarabah ventures, therefore, is open to

(5) See Muhammad Abdurrahman Sadique, “A study of equity financing modes”, p. 193. 
question. Financing on the basis of musharakah/mudarabah does not result in the creation of any debt. Therefore, in the context of Islamic banking, it seems unjustifiable that the mechanism adopted for the calculation of a fixed return in debt financing itself be employed in connection with equity financing, where the purpose is mutual sharing of an uncertain amount of profits to be realized.

Based on the above, it appears essential that Islamic banks strive to move away from the currently adopted capital / period based calculation mechanism for determining its own profit share, to an objective method aimed at determining the profit sharing ratio in the equity venture as a whole. Ideally, a profit sharing ratio could be fixed for an individual venture considering relevant aspects that are of importance to each partner, based on independent negotiation. This would result in a fair share of the profit accruing to the bank, in proportion, at least partially, to the amount of funds invested and any expertise extended, while the client, too, secures a fair return for his input in the form of capital or labour. Although there could be no bar to using the rate of return / period method for purposes of analysis and comparison, adopting it as the very basis of profit share calculation does not seem to be reflective of the spirit of equity participation.

\section{Shariah Directives on the Ideal Profit Sharing Ratio}

The profit sharing ratio agreed on by partners in an equity venture is usually regarded as a business decision taken by the partners solely at their own discretion. However, a closer inspection could reveal certain aspects of crucial importance that are relevant in this regard. A fundamental principle in the theory of equity relationships in Shariah is that loss should always be suffered by equity partners proportionate to their capital exposure. No alteration of this ratio is admissible ${ }^{(6)}$. In view of this constant principle, an equitable division of profits could demand that, although profit sharing could be agreed on a footing other than that of loss sharing, the difference between the two ratios should not be extreme in nature that the partner with a minimum capital input succeeds in securing a maximum share of profits, in spite of bearing the liability of only a fraction of any possible loss. Similarly, the partner that invested a major part of the capital, thus bearing the greater portion of liability, should not be rewarded with only a meagre share of profits. Thus, profit ratio agreed in an ideal environment should bring about a fair share of the proceeds to each partner and adequately consider the level of liability he had borne, among other factors.

(6) Ibn Qudamah, al-Mughni, vol. 5, p. 147, Al-Sharbini, Mughni al-Muhtaj, Bayrut, Darul Fikr, 1998, vol. 2, p. 292. 
Due attention has been paid to this vital aspect by schools of Islamic law, although differing in details. Thus, the ideal propounded in this regard, upheld by the Shafi'i and the Maliki schools as the only correct basis, and permitted by the Hanafi and the Hanbali schools, is that the profit ratio should be in total conformity to the capital participation ratio ${ }^{(7)}$. Even though the client / partner could be given a higher share in view of the higher input of labour on his side as permitted by the latter two schools, the profit share of the major capital provider preferably should not be minimal, as the higher risk element too demands just consideration. This is borne out by the fact that the Hanafi school, despite of recognizing a departure from a profit sharing ratio strictly based on the capital participation ratio, thus justifying an increase of the profit share in order to compensate for skill and labour, has imposed the restriction that a profit share exceeding the capital input ratio may not be agreed on for a partner who has expressly absolved himself of the responsibility of labour, as there would be no justification for the excess in this instance. This could possibly signify the fact that while a departure is condoned for compensating for labour, the original basis for division of profits is that of capital participation.

Therefore, the Shariah concept of equity relationships ideally appears to favour a profit sharing ratio that is maintained as close as possible to the ratio of capital participation, except when other related factors such as disproportionate levels of skill and labour contributed by the partners demand a departure from this basis ${ }^{(8)}$. Hence, in the context of equity ventures embarked on by Islamic banks, the ideal on profit sharing appears to be that it should be reflective of the capital outlay of the bank and the client to the extent possible. In the case of mudarabah financing where the whole capital comes from the bank, a sizable portion of the profit should thus accrue to the bank in view of its capital infusion. Adopting a mechanism that operates on a radically different basis where this vital aspect is totally disregarded cannot be held to be indicative of the spirit of Islamic equity relationships.

(7) See references above.

(8) It is worthwhile to note here that the Maliki perception of shirkah demands that the element of labour contributed by the partners, too, be in proportion to the capitals invested. The Maliki school is noted for the stress it places on the notion of equality / proportionality in all aspects of shirkah. Apparently, if the Hanafi explanation in a similar instance is to be applied here, this requirement only indicates that there should not be any condition to the effect that a partner would contribute less than the amount of labour proportionate to his capital, or that he would be absolved of the responsibility of labour. Otherwise, it is taken for granted that the labour provided the partners is in proportion to their capital. See Ibn Rushd al-Qurtubi, Bidayah al-Mujtahid, al-Qahirah, Maktabah al-Kulliyyat al-Azhariyyah, 1969, vol. 2, pp. 275, 277, al-Kasani, Bada 'i' al-Sana'i', vol. 6, p. 100. 
The capital provided by the investors of the bank happens to be risk capital, extended at the cost of liability. It would be well to remember that risk capital differs to a great extent from loan capital such as capital that is lent to the bank by depositors. As such, it would be natural if the former comes with significantly higher demand on profits. An Islamic bank is expected to promote the interests of its investors, who provide capital for investment and justifiably expect a fair return on funds extended by them. If the above ideal pertaining to the profit sharing ratio in ventures financed could be brought into reality at least in a partial manner, it would forthwith result in adequately rewarding the investors of the bank whose funds are made available to entrepreneurs through the bank's intervention.

The nature of exposure in the equity venture itself merits a distinction from investment through debt financing products such as murabahah. The fundamental difference between debt financing products and equity financing modes is that, while the former results in the creation of a debt that is owned by the bank and is usually secured by collateral, the latter does not lead to entitlement to any debt. Therefore, while the former may not end in the loss of capital except in extraordinary circumstances, such possibility is far from being nonexistent in the latter mode of financing. The equity platform adopted ensures that the partners are wholly liable for their respective shares of capital, and consequently, in the event of a natural business loss, the partners necessarily have to bear it with good grace. Therefore, in equity financing where the risks are considerably higher, it would seem proper that the profit ratio should appropriately reflect the risk on capital.

However, constraints imposed by the availability of cheaper loan capital provided by conventional banks could preclude the possibility of demanding a just return for the risk capital forwarded by the investors of Islamic banks. Thus, market realities appear uncooperative, if Islamic banks were to demand due recognition of their risk capital. In these circumstances, the minimum that could be done appears to be taking effort at gradual progress towards the ideal, by adopting a basis of objective negotiation for fixing the profit sharing ratio taking all relevant factors into consideration, instead of calculating it solely on the basis of the rate of return sought and the period of exposure in a unilateral manner.

\section{Profit Ratio Calculation Based on Capital and Labour Contributions}

It was indicated above that the profit ratio calculation method generally adopted by Islamic banks at present stands in need of a genuine review. It could be pertinent at this juncture to attempt at suggesting some possible alternatives 
that are more reflective of the shariah ideal, which could be sought to be implemented in situations where Islamic financial institutions enjoy sufficient freedom and support enabling them to function in a fully independent and vibrant manner ${ }^{(9)}$.

It is essential in this respect to explore the guidelines provided by the Shariah in the context of determining the profit sharing ratio. It was mentioned earlier that Shafi'i and Maliki schools hold that the profit division ratio should necessarily correspond to the capital participation ratio, any agreement to the contrary resulting in the invalidity of the shirkah ${ }^{(10)}$. Hanafi and Hanbali schools allow that the agreed profit ratio could differ from the capital participation ratio, subject to the restriction by Hanafi jurists alluded to above. It is important to examine the grounds on which they justify such a departure from adopting the ratio of capital contribution.

An examination of Hanafi and Hanbali texts bears out that in addition to capital, they also recognize labour and liability as possible foundations for entitlement to profit ${ }^{(11)}$. Liability always accompanying capital except in certain specific situations ${ }^{(12)}$, the recognized bases for entitlement to profit could essentially be regarded as two, i.e. capital and labour ${ }^{(13)}$. Hanafi jurists have explained through citing various combinations of capital, profit and labour that a share of profit agreed in excess of what is proportionate to a partner's capital is justified on the basis of labour that falls on him. In this instance, profit proportionate to his capital is deemed to be entitled on the basis of capital, while

(9) Researchers have highlighted that determining the exact mechanism by which profit and loss should be determined is one area where more needs to be done. The profit sharing mode of finance does not readily provide a systematic mechanism by which profit shares are arrived at. A market solution could be reached when the system is generalised to cover a greater number of participants. See Mohammed Akacem, Lynde Gilliam, "Principles of Islamic banking: debt versus equity financing" (March 2002) vol. 9, No. 1 Middle East Policy, p. 124(15).

(10) A weaker position of the Shafi'i school holds that if a share greater than what is proportionate to his capital is stipulated for one partner due to some specific labour contributed by him alone, the stipulation is valid, and he may claim the excess share against the labour. The contract is considered to consist of a shirkah and a qirad in this instance. However, according to the preferred position upheld in the Shafi'i school, the stipulation is invalid, and the profits are divided according to the capital ratio, the partners being entitled to just recompense from each other for the labour they had performed in the share of each other. Al-Nawawi, Rawdah al-Talibin, vol. 3, p. 516.

(11) Al-Kasani, Bada 'i' al-Sana 'i', vol. 6, p. 100, Ibn Qudamah, al-Mughni, vol. 5, p. 140, 141.

(12) e.g. when a mudarib becomes liable for the capital; in this instance, the mudarib is entitled to the whole profit due to his bearing the whole liability, although the capital was not invested by him. It could be seen that even in this situation where capital and liability are separate, liability is proportionate to capital. See al-Kasani, Bada' 'i' al-Sana' $i$ ', vol. 6, p. 99.

(13) The author of al-Hidayah has mentioned only these two in discussing shirkah al-'Inan. See Ibn al-Humam, Fath al-Qadir, Bayrut, Darul Fikr, (n.d.), vol. 6, p. 177. 
the excess is regarded as the fruits of the labour he was responsible for ${ }^{(14)}$. Where labour is assigned to one of the partners, the other partner may not be entitled to a share of profits larger than what is proportionate to his capital, as the excess cannot be justified in this instance ${ }^{(15)}$. In Hanbali law, the ruling is similar, although there is a difference regarding the categorisation of this contract. According to Hanbali jurists, when labour is assigned to one partner alone, it is perceived as an admixture of shirkah and mudarabah, as shirkah al'inan according to them necessarily requires sharing in capital and labour both. In this instance, the partner cum rabb al-mal may not claim a profit share higher than the proportion of his capital, as the excess share of profit stipulated is not supported by either capital or labour, and thus becomes void ${ }^{(16)}$.

It is seen from the above that the basis of recognizing a departure from adopting the capital participation ratio for profit division is the element of labour. Hanafi jurists explain the need for such differentiation by arguing that one of the partners could happen to possess more expertise and insight and be capable of carrying out a larger amount of work, and thus might not agree to enter the partnership on equal terms ${ }^{(17)}$. Hanbali jurists' justification is similar, who say that this entitles the partner in this instance to stipulate an extra (share of) profit against his labour ${ }^{(18)}$. Thus, the element of labour, that comprises skill, technical know-how, experience, potential etc, to which we may add market reputation and goodwill as well, has been regarded as the second primary factor that has been allowed to have an impact on fixing the profit sharing ratio ${ }^{(19)}$.

(14) Al-Kasani (Bada' i' al-Sana' $i$ ', vol. 6, p. 100) states: "if the two capitals are unequal, and the partners had stipulated equality in profit, ... it is permissible, ... when they had stipulated the labour on both of them; excess of profit for one of them over the proportion of his capital is due to his labour".

(15) See al-Kasani, Bada'i' al-Sana 'i', vol. 6, p. 100.

(16) Ibn Qudamah, al-Mughni, vol. 5, p. 141.

(17) Al-Marghinani, al-Hidayah, printed with Ibn al-Humam, Fath al-Qadir, vol. 6, p. 177.

(18) Ibn Qudamah, al-Mughni, vol. 5, p. 140.

(19) It can be seen that these two factors have been recognized as the primary elements that could influence the individual profit shares of the partners, as these are the factors that are variable with regard to each partner. Capital and labour could engage each partner individually in a manner different from the other, as each partner comes with a specific amount of capital not necessarily equal to the other, and could contribute a distinct share of labour different from that of the other in quantity or quality. As far as the other relevant factors such as time and risk are concerned, these are noted to be applicable to the venture as a whole. The period taken for completion of the project, i.e. the period of capital exposure, equally applies to both partners, as the capitals of both partners would be engaged until liquidation. Similarly, the element of risk, too, is relevant to the venture as a whole, after the partners have invested their capitals in operations. Any loss befalling the assets would generally affect both partners. Thus, such factors possibly may not justify the alteration of the profit share of one partner alone to the exclusion of the other. 
Although the schools that admit the disparity between profit ratio and capital ratio have identified labour as the element that justifies it, they have not considered it necessary to provide any guidelines about the scope and nature of the role of labour in altering the profit ratio, and have left it to the discretion and mutual agreement of the partners. The result is that while the role of capital in fixing the profit ratio is clear and unambiguous, that of labour is dependent on the arrangement of the parties. In practice, this would mean that the partners could fix any ratio for this purpose subject to the foregoing restriction, and once fixed, the difference between the ratio adopted thus and the capital investment ratio would be justified on the basis of the labour input of the partners ${ }^{(20)}$. The reason obviously could be that the nature of each equity relationship being different, the partners should be allowed to arrive at a profit sharing ratio that adequately rewards the labour of each of them, through free negotiation. The nature of the labour of each being unique in one way or the other, any share of the profit could be agreed on through mutual consent as its reward. Nevertheless, the basis for entitlement to profit in all cases is recognized as capital and labour, as shown above.

It should be noted that in the case of equity ventures involving non-banking entities, a ratio mutually agreed for profit sharing would usually concern the partners as individuals or individual business firms, the outcome of which would usually be restricted to the partners themselves or to a limited segment of individuals. It would not in general be expected to carry economic and social repercussions on a large scale. Therefore, any ratio adopted by the partners for this purpose (subject, of course, to the restriction mentioned above) is upheld by the above schools as a fair division of profits that adequately rewards each partner for the capital and labour provided by him, based on his choice and free will.

However, in the case of Islamic financial institutions, fixing the profit sharing ratio could not be considered solely a business decision involving only the bank and a limited group of people. Islamic banks are expected to play a fundamental role in directing the process of wealth distribution among the populace, as opposed to that played by conventional banks which aids a system leading to concentration of wealth ${ }^{(21)}$. Islamic banks are duty bound to secure a

(20) The similarity of the Hanafi jurists' stance in this question to that in the exchange of ribawi items in combination with non-ribawi items is noteworthy. Where an item of riba is exchanged with a similar item that is combined with a non-ribawi item, the Hanafi school permits the transaction provided the single ribawi item is larger in quantity than the ribawi item constituting the other counter value. The difference, irrespective of its amount, is taken as the value of the non-ribawi item, and the transaction is justified on this basis. This is discussed as mas 'alah mudd 'ajwah in works of fiqh. See al-Sarkhasi, al-Mabsut, vol. 12, p. 189.

(21) Muhammad Umer Chapra, Islam and the Economic Challenge, Leicester, The Islamic Foundation, 1992, pp. 328, 183. 
fair return for their investors, who have invested their funds with the bank on a profit and loss sharing basis, exposing their savings to the risk of loss. Thus it would seem appropriate that, paying due attention to the socio-economic function they are supposed to perform, Islamic banks should be enjoined to adopt a more regular and uniform method in this regard that succeeds in realizing this objective.

If Islamic financing is to materialize in the true sense, it could be expected that a significant number of the facilities extended for financing purposes would be offered on an equity platform. Therefore, it is vital that Islamic banks possess a consistent and standardized method that could serve as the basis for profit ratio calculation, that primarily takes the contributions of the partners in the form of capital and labour into consideration, while allowing flexibility for negotiation. It is important that such a method be simple and transparent so that the clients could readily comprehend its application, and negotiate for adjustment where necessary. We proceed to explore below some possible methods that could be employed for this purpose if the proportions of the partners' capital and labour inputs both are to be considered for determining the profit sharing ratio. These primarily pertain to financing ventures on the basis of joint equity, i.e. musharakah, where the bank as well as the client partner both may contribute towards the capital and labour necessary for the venture.

In such ventures, it is evident that the capital investment ratio could be ascertained with little difficulty. The primary concern appears to be in determining the labour contribution ratio and how it relates to the capital ratio so as to arrive at a profit division ratio that is reflective of both. With regard to the labour component in equity partnerships, two primary bases appear possible. One is to consider the labour element in all partnerships to be of equal importance to the capital in determining the profit ratio (equal weightage method), and the other is to give the labour component different degrees of weightage in relation to the capital component according to the nature of the venture (adjusted weightage method) ${ }^{(22)}$.

\section{Equal Weightage Method for Capital and Labour}

In this method, the aggregate labour is considered equal to the aggregate capital in the creation of profits. This would require that when the partnership enterprise is taken as a whole, the capital element be taken to comprise two equal components, namely, the monetary capital and the labour capital. This

(22) See Muhammad Abdurrahman Sadique (2006), "A study of equity financing modes for Islamic financial institutions in a Shari'ah perspective," unpublished doctoral thesis, International Islamic University Malaysia. 
could be justified on the basis that capital, however large it be, would never give rise to profits if left alone. Involvement of labour, or in other words, entrepreneurship, which in the Islamic sense would include raw labour as well as expertise and management, is imperative for the creation of profits through capital. Consequently, labour and capital could be assigned equal weightage in the allocation of profits. This leads to the supposition that half the profits is resultant of capital while the other half is resultant of labour. As far as the half that is based on capital is concerned, its allocation between the partners is clear: it should be shared on the basis of the capital participation ratio. With regard to the other half of profits that is based labour, the ratio of labour contributed by the parties should be estimated for determining its allocation. When the labour contribution ratio in a particular venture is thus assessed, now the preliminary profit sharing ratio could be calculated taking both the capital ratio and the labour ratio into consideration. Combining the capital and labour ratios would result in the partners' combined input ratio, which could be adopted as the profit sharing ratio directly, or after some modification based on negotiation.

\section{Quantification of labour}

For assessing the ratio of the partners' labour inputs, it is necessary to estimate the labour contributed by each partner. Due to this estimation taking place before the commencement of partnership, it is not possible to quantify the actual amounts of labour that will be contributed by the partners towards the venture. Hence, the labour agreed to be undertaken by the parties could be taken to serve as the basis for calculation of the ratio. As mentioned above, this is also validated by the clarification of the Hanafi jurists justifying disparity in profit allocation. Quantification of labour, although appearing to be daunting at the first glance, is not beyond the realm of possibility. A possible method that could be adopted in this regard is the assessment of the wages needed to be paid if the partners hired outsiders for carrying out their respective roles, which could provide a fairly accurate comparison of the labour contributed by the partners. It should be kept in mind that the purpose is merely to arrive at the ratio between the amounts of labour to be undertaken by the partners, i.e. to ascertain the proportion of the labour of one partner in relation to that of the other. Therefore, the period supposed to be taken for the completion of the enterprise is not of importance, as the factor of time equally applies to both the partners generally. As such, even if the time element is allowed to play a role, it would be redundant in arriving at the ratio.

Quantification of labour is a concept well-recognized in all the schools of Islamic law, even within the purview of equity financing itself. In the case of shirkah as well as mudarabah, where the contract becomes invalid due to some reason, the majority of schools have advocated the need to quantify labour 
contributed by the partners towards the venture in various instances, in order to assess the fitting recompense (ujrah al-mithl) each partner is entitled to from the other ${ }^{(23)}$. Although it could be observed that here the quantification takes place after the labour had been contributed and thus the situation is different from prior ascertaining of the labour to be undertaken, it cannot be denied that the concept of assessing labour is well-grounded in Islamic law. Moreover, while in invalid shirkah and mudarabah exact assessment is necessary as recompense to the parties would be based on it, in the present instance, the purpose is only to arrive at a basic profit sharing ratio, which could be adopted with mutual agreement as it is, or further adjusted through negotiation.

It is not necessary that the bank carry out this process with every customer. Equity based facilities granted by the bank could be classified into some major categories, so that most of the facilities fall into one category or the other. The proportion of the labour carried out by the bank and the client in each of these categories could be assessed. It should be noted that with regard to the bank's labour, what should be taken into consideration is the labour undertaken to be performed by the bank towards the venture in some manner ${ }^{(24)}$. This could include, in an export oriented equity venture for example, tasks such as handling of export documentation, liaising with the importer's bank and collection of payment. The rest of the activities such as finding of suppliers and overseas buyers, purchase and preparation of the consignment, handling shipping procedure etc. would be the responsibility of the client/partner ${ }^{(25)}$. Since the proportion of labour thus carried out by the bank and the client could be similar in most exports involving a single type of goods, a general labour ratio could be fixed with regard to a single type, which could serve as the basis for further negotiation where necessary. Adjustments could be made in view of the quantity exported or any noteworthy reputation enjoyed by the client etc where relevant. Thus, predetermined labour contribution ratios could be made available with regard to most of the equity ventures financed by the bank. If this

(23) In invalid shirkah, Maliki, Shafi'i and the Hanbali schools prescribe ujrah al-mithl, while in invalid mudarabah, all the four schools do so. In some forms of invalid mudarabah, the Maliki schools prescribes qirad al-mithl. See for shirkah: al-Sharbini, Mughni al-Muhtaj, vol. 2, p.292, al-Khurashi, Hashiyah al-Khurashi, vol. 6, p. 349, Mansur ibn Yunus alBahuti, Kashshaf al-Qina', Bayrut, Dar al-Fikr, 1982, vol. 3, p. 505, Ibn Qudamah, alMughni, vol. 5, p. 128; for mudarabah, see: Ibn Rushd al-Qurtubi, Bidayah al-Mujtahid, vol. 2, p. 263, Ibn Qudamah, al-Mughni, vol. 5, p. 188.

(24) Tasks performed by the bank prior to becoming a joint partner in the equity venture with the client such as credit evaluation of the client may not be included in the labour towards the venture.

(25) With gradual increase of Islamic banks' experience in active participation in trading operations as a genuine equity partner, the scope of the bank's involvement in such ventures could rise to include aspects such as finding of suppliers and overseas buyers and handling local purchase etc. too, thus enhancing the role played by the bank. 
could be accomplished, complete assessment of labour would become necessary only in equity ventures that are uncommon in nature or happen to be unusually large. Although the preparation of a table of such ratios requiring a fair amount of effort could perhaps be strenuous and demanding for a single institution, it would not be hard to formulate if embarked on by a general body of Islamic banks in a country or state that has access to the necessary market information and resources. When a common set of ratios pertaining to ventures that could be financed on equity basis has been prepared, each bank could formulate its own table of ratios based on the level of its own involvement in different types of ventures, by making adjustments to the general set of ratios.

After assessing the labour contribution ratio in a particular venture in this manner, the capital contribution ratio would be combined with it, in order to arrive at the proportion of the partners' cumulative contributions towards the venture. We may call this the aggregate capital ratio. This ratio could be taken as the basis for sharing profit between the bank and its partner either directly or after some adjustment in view of any business consideration, based on negotiation.

\section{Illustration 1}

Let us take the example of a proposed equity venture for the export of palm oil. The capital outlay required has been assessed at RM one million, of which RM 700,000/=, i.e. $70 \%$, will be provided by the bank. The FOB price has been agreed at RM 1.15 million. The procurement and shipping of the consignment would take one month, while the overseas buyer requires supplier's credit for three months. Let us assume that the labour ratio in similar palm oil exports has been determined at 10:90, which means that the bank's labour input towards the venture would amount to $10 \%$ of the total labour required. Combining the capital input ratio of 70:30 and the labour input ratio of 10:90, we arrive at the aggregate input ratio of $80: 120$, which is equal to $40: 60$. Thus, the basic profit sharing ratio could be agreed at 40:60, or a variation of it as fixed after negotiation.

As evident from the above, the amount of the capital provided by the bank or the period taken for receipt of payment does not play a role in fixing the profit share of the bank. The profit ratio is fixed solely on the basis of the proportion of the capitals contributed towards the venture and the relevant ratio of labour contribution. The above example could be illustrated through the following diagram (Fig 1). 


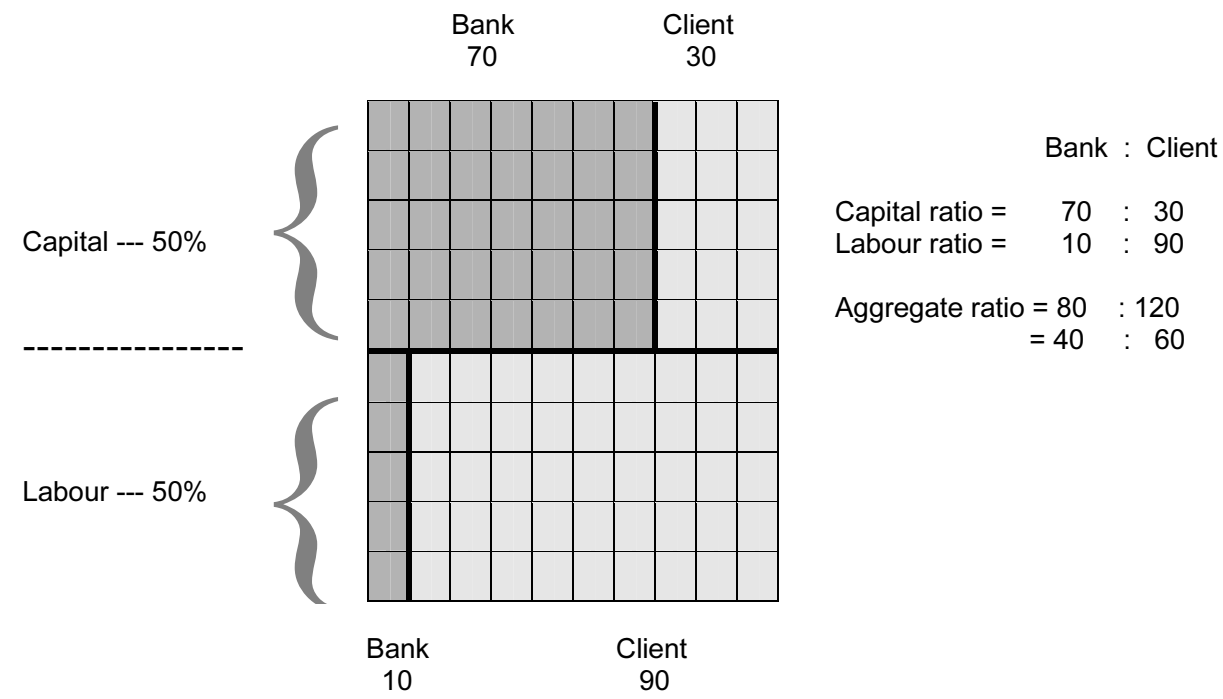

Fig. (1). Determining profit sharing ratio based on capital and labour contributed by partners through Equal Weightage Method.

\section{Adjusted Weightage Method for Capital and Labour}

In this method, the labour component is not considered equal to the capital component in the creation of profits. Thus, it is not assumed that capital and labour both could lay claim to profits equally. This method takes into consideration the fact that in certain ventures, the existence of labour, although vital, does not influence the profitability of the venture as much as the capital does. An example could be the supply of items such as certain foodstuff that enjoy a ready market throughout the year, where instant sale is assured upon procurement. The labour or expertise required in order to make profits in these ventures happens to be minimal. Such ventures could be regarded as capitalintense enterprises, where the profitability almost wholly depends on the volume of capital. Conversely, in certain other enterprises, profitability may depend to a great extent on labour related factors such as the volume of effort, expertise, awareness of the market, reputation, etc. In these ventures, profits are not assured due to the existence or volume of the capital alone. These could be regarded as labour-intense enterprises.

From this perspective, assigning profits equally to capital and labour would be justifiable only in the case of ventures where profitability depends on both these factors equally. This calls for allocating different weightages to capital 
and labour, based on the nature of the particular enterprise. Thus, beside the labour contribution ratio of the bank and the client, another ratio would need to be ascertained, namely, capital and labour weightage ratio pertaining to the relevant venture. This ratio would reflect the proportion of the involvement of capital and labour elements in generating profits. In a capital-intense venture, even if the whole labour is provided by one partner, that alone would not entail the allocation of half the profits to him, as the weightage of labour would be relatively less. Therefore, the aggregate capital input ratio discussed above, which reflected the proportion of cumulative contribution of capital and labour by the bank and the client, would need to be adjusted further, in order to reflect the weightage of labour as compared with that of capital in the particular type of venture involved. The aggregate capital ratio adjusted in this manner may be called the weighted capital input ratio. This ratio would be indicative of the proportion of the capital cum labour input by the bank and the client, after being modified to reflect the relative significance of labour as against capital. The weighted capital ratio could be adopted as the ratio for profit sharing between the bank and the client, either as it is, or after some amendment based on negotiation.

\section{Assessing Capital and Labour Weightage Ratio}

Adjusted weightage method requires determining the weightages of capital and labour pertaining to different types of ventures. For this purpose, the proportionate significance of each needs to be assessed. The total capital as well as the total value of the labour contributed by both partners would have to be ascertained for arriving at the ratio of the two. Again, a guide to the value of the total labour required from the partners in bringing the project to a completion could be found in assessing the total expense necessary if their respective roles were to be outsourced. After quantifying the total labour ${ }^{(26)}$ required thus, this can be compared with the total capital for determining the weightage ratio of capital and labour. This would provide an indication of the level of involvement

(26) It should be understood that what is meant by total labour here is the total effort undertaken by the partners towards the venture, that is rewarded by a share in the profits. This is the element of human effort which forms part of the Entrepreneurial Factors of Production or profit-sharing factors, in conjunction with other elements such as financial capital, riskbearing etc, according to the classification by some Muslim economists (See M. Fahim Khan, Essays in Islamic Economics, Leicester, The Islamic Foundation, 1995, p. 15). The purport here is the element of labour or entrepreneurship contributed by the partners, in addition to contributing financial capital, which deserves a share of the profit. It does not mean the expense for hiring employees for carrying out various tasks and duties in the course of operations, as is usually meant by labour in accounts. Such labour costs are part of the expenses of the venture similar to purchases, utilities, and transport, and are borne by the financial capital (which are referred to as Hired Factors of Production or ujrah (rent) receiving factors in the above classification). 
of labour as against that of capital, in realizing profits. The aggregate capital ratio could be adjusted using the weightage ratio to arrive at the weighted capital ratio, which would provide a more realistic notion of the capital cum labour contribution of each partner towards the venture, that can serve as the basis for sharing profits.

If this is to be implemented, a careful study of various ventures would have to be carried out in order to decide the capital and labour weightage ratio pertaining to them. As explained above in the discussion on determining the partners' labour contribution ratio, the capital and labour weightage ratio need not be ascertained with regard to every venture sought to be financed on an equity basis. Many of the ventures could be classified into major categories, and the capital and labour weightage ratio could be determined with regard to such categories. Again, this task is best carried out by a general body representing Islamic banks in a country or a region. Such a body could prepare tables of both capital and labour weightage ratio and partners' labour contribution ratio with regard to different types of ventures, which could be used by Islamic banks for calculating the weighted capital ratio, which in turn could serve as the basis for negotiating the profit sharing ratio with the clients.

\section{Illustration 2}

The previously mentioned example concerning the palm oil export venture could again be used here to illustrate how the adjusted weightage method would apply in determining the profit ratio. It was mentioned that the total capital required for the venture being RM one million, the capital input ratio by the bank and the client stood at $70: 30$, while the labour input ratio by the bank and the client in similar ventures is assessed at 10:90. However, in employing adjusted weightage method, we cannot give equal weight to both capital and labour. Therefore, these two ratios cannot merely be combined. Let us assume that the capital labour weightage ratio in similar ventures has been assessed at $80: 20$, i.e. 4:1. This would mean that the capital element is as four times significant as labour in generating profits in such ventures. Hence, considering labour to be at par with capital in entitlement to profit is clearly unjustifiable. Therefore, both the capital ratio and the labour ratio would have to be adjusted to reflect this reality, before combining them to find out the proportion of the total contributions by the bank and the client. Since the weights of capital and labour are different, we could express the ratios thus:

Capital input ratio;

Labour input ratio;
Bank Client

70C : 30C

$10 \mathrm{~L}: 90 \mathrm{~L}$ 
Combining these two, we obtain,

Aggregate capital ratio; $\quad 70 \mathrm{C}+10 \mathrm{~L}: 30 \mathrm{C}+90 \mathrm{~L}$

However, as capital is as four times effectual as labour, $\quad \mathrm{C}=4 \mathrm{~L}$ we obtain,

Weighted capital ratio; $\quad 58 \quad: \quad 42$

Therefore, the profit sharing ratio between the bank and the client could be agreed as $58: 42$, or a similar ratio based on this fixed through negotiation.

This position could be illustrated through the following diagram (figure 2).

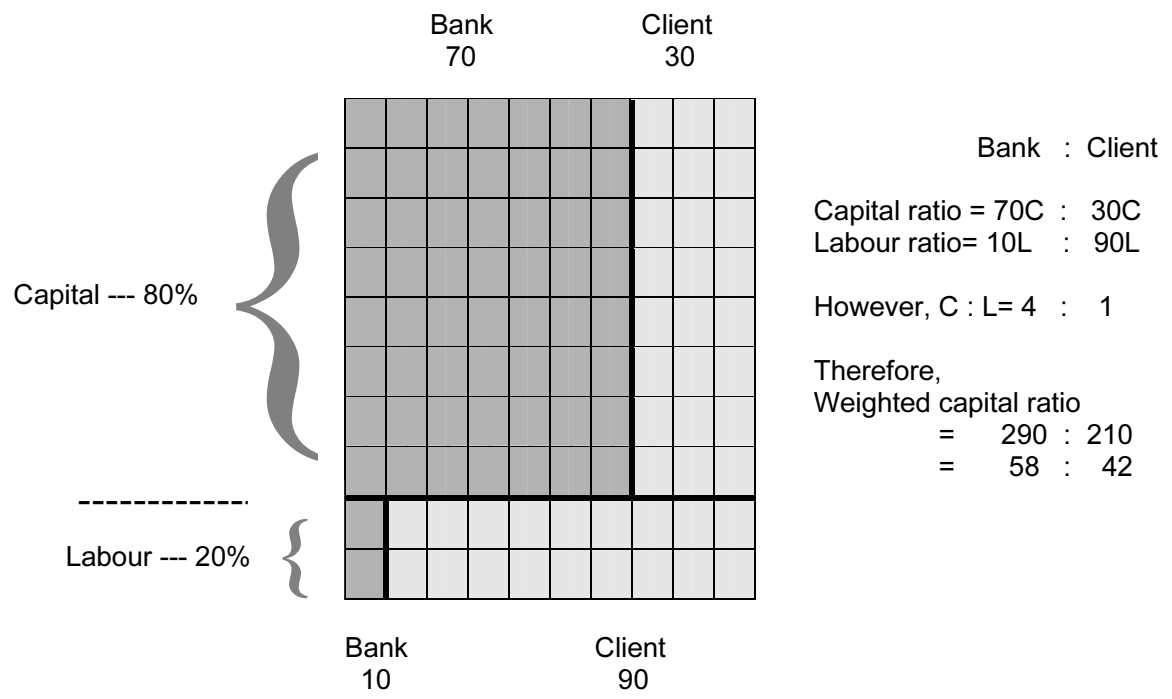

Fig. (2). Determining profit sharing ratio based on capital and labour contributed by partners through Adjusted Weightage Method.

Comparing this with the aggregate capital ratio of $40: 60$ arrived at using the equal weightage method above, it can be observed that the profit share claimed by the bank has increased from $40 \%$ of the total profit to $58 \%$ of the total profit. This is because adequate attention is paid in the adjusted weightage method to the relative importance of capital and labour.

\section{Evaluation of the Above Methods}

Adopting the adjusted weightage method as the basis for determining the profit sharing ratio could lead to a more equitable sharing of profits between the bank and the joint partner, as due attention is paid in this method to the 
proportionate significance of both capital and labour in the creation of the profits. It can be presumed that in most instances, using this method would result in the bank's entitlement to a just share of profits as the major provider of capital, as here the labour component is not assigned an equal share in the profits automatically. This would in turn reward the investors of the bank adequately, who are the original providers of capital. Equal weightage method, while taking the labour component of both partners into consideration, disregards the relative import of capital and labour vis-à-vis each other, and assigns labour a share of the profits equal to that of capital. This could generally be favourable to the client as the joint partner of the bank, as the bulk of the labour could be presumed to come from him. Both methods appear preferable to determination of the profit ratio on the basis of rate of capital return and period, as being mechanisms built on a fair appraisal of the partners' inputs, they could be considered to be more reflective of the spirit of Islamic equity financing. In addition, they do not embody the negative aspects inherent to the rate of capital return cum period method, which is primarily structured for interest based lending, and appears anomalous when employed on an equity platform ${ }^{(27)}$.

It was mentioned earlier that these methods would primarily be applicable in ventures financed by the bank on musharakah. In mudarabah financing where the whole capital comes from the bank and the client's contribution is limited to his expertise and labour, application of the equal weightage method would not be directly meaningful. If applied, it would require that the bank and the client partner (mudarib) share profits equally. This, although justifiable, may not be a lucrative option for many entrepreneurs seeking finance. However, as far as the adjusted weightage method that is based on the capital and labour weightage ratio is concerned, this method could provide a valuable guide to determining the profit sharing ratio in mudarabah. The capital and labour weightage ratio pertaining to the relevant venture could be adopted as the basic ratio for profit sharing, if necessary after some adjustment based on negotiation, as an equitable alternative to the current method based on employing the rate of return on capital. In ventures where the labour plays relatively a larger role in generating profits, this method would enable the entrepreneur to be entitled to an adequate share ${ }^{(28)}$.

(27) See evaluation of the current method based on rate of return and period of exposure above.

(28) It could be suggested that if the above methods are found to be viable in the context of musharakah financing, a bank may advantageously adopt the musharakah basis even for financing those ventures where the client applies for a mudarabah based facility. This can be done through requiring the client to contribute at least a small portion of the necessary capital outlay, thus justifying a musharakah platform, in which event the capital and labour of both parties may be taken into consideration in fixing the profit sharing ratio. 
However, in the current environment dominated by conventional banks providing loan capital at low rates of interest, adopting the adjusted weightage method does not appear realistic, as it would result in the entrepreneurs sacrificing a larger share of profits against the prospect of availing of risk capital $^{(29)}$. Therefore, aiming to adopt the equal weightage method, where contribution of labour by the client is considered equal to his providing capital and therefore is similarly rewarded, appears to be a more pragmatic goal that could be striven towards by Islamic banks. As mentioned earlier, it is not mandatory that the aggregate capital ratio ascertained through this method be adopted as it is as the profit sharing ratio. It could be further adjusted based on negotiation between the client and the bank where necessary. A final balance in the policy of banks regarding profit ratios could be expected to materialize through the operation of market forces in the form of increased patronage of investors and applicants for equity based facilities ${ }^{(30)}$. What appears important at this juncture is to abandon the application of rate of return / period as the basic method for fixing the profit share of the bank even in equity ventures, thus marking a clear turning point in implementing the spirit of Islamic equity financing. The methods explored above attempt to present an outline of means that could be employed for this purpose, after further analysis and fine-tuning by practitioners and experts in the field.

\section{References}

Akacem, Mohammed and Gilliam, Lynde (2002) "Principles of Islamic banking: Debt versus equity financing." Middle East Policy 124(15).

al-Bahuti, Mansur ibn Yunus (1402H) Kashshaf al-Qina', Bayrut: Dar al-Fikr.

Chapra, M.Umer (1992) Islam and the Economic Challenge, Leicester: The Islamic Foundation. Ibn al-Humam, Kamal al-Din (n.d.) Fath al-Qadir. Bayrut: Darul Fikr.

(29) In the contemporary scenario, banks use the amount of capital provided by the bank multiplied by the monthly rate of return on capital and the expected period of exposure in months, for arriving at the return sought to be secured by the bank. In the current example, if we assume that the rate of return was $2 \%$ p.m., the duration as stated being 4 months, this would amount to RM $700,000 \times 2 \% \times 4$, i.e. RM 56,000 . When compared with the total expected return of RM 150,000 as in the example, this indicates a ratio of $37.33 \%$ of the total profit as the profit share of the bank. An adverse factor in this process is that even if the expected profit happened to be double the amount given in the example, this alone would not be taken as a basis usually for the bank demanding a higher return. Typically, the bank would adhere to the set rate of return on capital, and the ratio of profit sharing would be fixed so as to realize the same amount of profit. Therefore, even when the profit expected to be realized happens to be RM 300,000, the rate of return applied would most probably not differ from the $2 \%$, resulting in a return of RM 56,000 for the bank. Due to the higher expected profit, the profit ratio of the bank in this instance would be fixed as $18.66 \%$ for shariah compliance.

(30) Nejatullah Siddiqi, Report of Working Group on The Monetary Theory of Islamic Economics, in Muazzam Ali (Ed.), Islamic Banks and Strategies for Economic Cooperation, London, New Century Publishers, pp. 81, 82. 
Ibn Qudamah, Muwaffaq al-Din 'Abdullah ibn Ahmad (1992) al-Mughni, Bayrut: Darul Fikr.

Ibn Rushd, al-Qurtubi (1969) Bidayah al-Mujtahid, al-Qahirah: Maktabah al-Kulliyyat alAzhariyyah.

al-Kasani, 'Ala al-Din (2000), Bada 'i' al-Sana'i', Bayrut: Dar El-Marefah.

Khan, M.Fahim (1995)Essays in Islamic Economics, Leicester: The Islamic Foundation.

al-Khurashi, Muhammad ibn 'Abdillah (1997) Hashiyah al-Khurashi, Bayrut: Dar al-Kutub al'Ilmiyah.

al-Marghinani, Burhan al-Din, Al-Hidayah, Printed with Ibn al-Humam, Kamal al-Din (n.d.), Fath al-Qadir, Bayrut: Darul Fikr.

al-Nawawi, Abu Zakariyya Yahya ibn Sharaf (n.d.) Rawdah al-Talibin, Bayrut: Dar al-Kutub al-'Ilmiyyah.

Obaidullah, Mohammed (2005) Islamic Financial Services. Jiddah: Islamic Research Center, King Abdulaziz University.

Sadique, Muhammad Abdurrahman (2006) "A study of equity financing modes for Islamic financial institutions in a Shari'ah perspective," unpublished doctoral thesis, International Islamic University Malaysia.

al-Sarkhasi, Abu Bakr (1406H) al-Mabsut, Bayrut: Dar al-Ma'rifah.

al-Sharbini, al-Khatib (1998) Mughni al-Muhtaj, Bayrut: Darul Fikr.

Siddiqi, Nejatullah (1982) Report of Working Group on the Monetary Theory of Islamic Economics, in Muazzam Ali (Ed.) (1982) Islamic Banks and Strategies for Economic Cooperation, London: New Century Publishers.

Siddiqui, Shahid Hasan "Instruments of Islamic banking in operation", http://jang.com.pk/thenews/apr2008-weekly/busrev-28-04-2008/p6.htm.

Taqi Usmani, Muhammad (2000) An Introduction to Islamic Finance. Karachi: Idaratul Ma'arif. 


\title{
توزيع الأرباح و الخسائر بين المصارف الإسلامية \\ و عملاء تمويل المشاركة: المنطق و المفاهيم و البدائل
}

\author{
محمد عبدالرحمن صادق \\ أستاز مساعد \\ قسم القانون الإسادمي - كلبة أحدد إبراهبم للحقوق \\ الجامعة الماليزية الإسلامية العالمية - ماليزيا
}

المستخلص. تقرر المصارف الإسلامية نسبة تقاسم الأرباح في

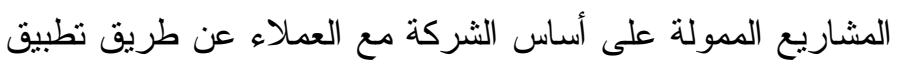

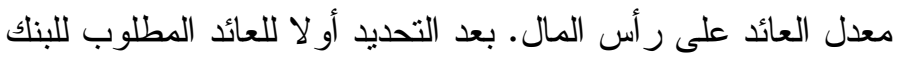

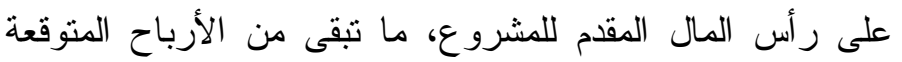
عادة ما يتخذ كحصة الثريك، وتعتمد النسبة كنسبة تقاسم الأرباح. هذا مع أن المنل الأعلى هو أن نسبة ثقاسم الربح يجب أن منأ

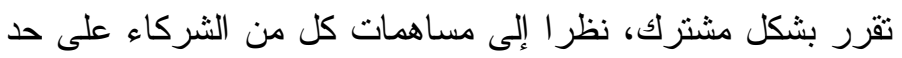
سواء، مع إيلاء الاعتبار الواجب لمستوى المسؤولية الذي يتحمله

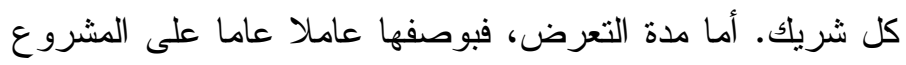

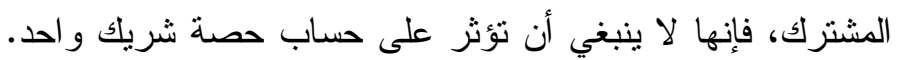

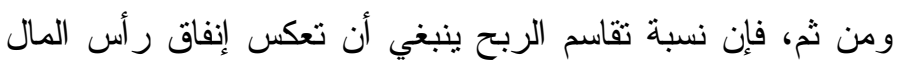

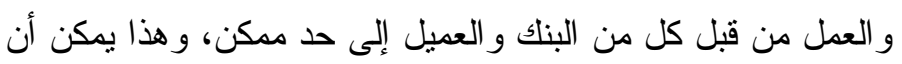

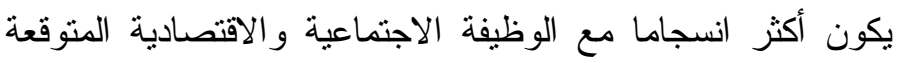

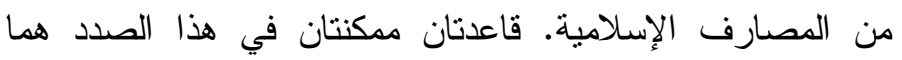

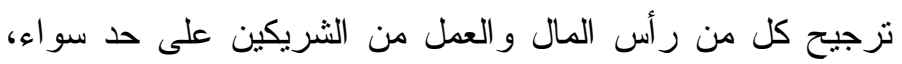
و إعطاء رأس المال نرجيحا مختلفا عن العمل. 